[Technical Report]

\title{
Design of Low Cost Pipe Fitting Device for High-throughput Screening Reactor for Screening of Methanol Synthesis Catalyst
}

\author{
Kohji Omata*, Masahiko Hashimoto, Yuhsuke Watanabe, \\ Sutarto, Tetsuo Umegaki, and Muneyoshi Yamada \\ Dept. of Applied Chemistry, Graduate School of Engineering, Tohoku University, \\ Aoba 07, Aramaki, Aoba-ku, Sendai 980-8579, JAPAN
}

(Received October 14, 2003)

\begin{abstract}
The high-throughput screening (HTS) reactor using the 96 well microplate system is useful for the optimization of $\mathrm{Cu}$ oxide catalyst for methanol synthesis. However, the number of parallel lines is sometimes insufficient for novel catalyst screening. Therefore, a low cost pipe fitting device and low cost HTS reactor for catalyst screening were designed.
\end{abstract}

Keywords

Combinatorial chemistry, High-throughput screening, 96 well microplate, Methanol synthesis

\section{1. 緒言}

触媒組成最適化の手法として, 多数の触媒の活性を並列的に 評価するHTS (High-Throughput Screening), 触媒のパラメータ 一（組成，調製条件等）と触媒特性（活性・選択性等）との間 の非線形な関係を表現する NN (Neural Network), 最適なパラ メーターの組合せを探索する GA（Genetic Algorithm）などを 組み合わせたツールを開発しメタノール合成用の $\mathrm{Cu}$ 系酸化物 触媒の組成最適化を進めてきた1) 8)。7成分系の $\mathrm{Cu}-\mathrm{Zn}-\mathrm{Al}-$ $\mathrm{Cr}-\mathrm{B}-\mathrm{Zr}-\mathrm{Ga}$ 酸化物触媒の組成最適化では, 96 ウェルマイクロ プレートを用いる HTS 反応器の) や, 実験計画法による NNの 学習用デー夕の設計 ${ }^{8)}$ などの手法を併用することにより一度の 実験で十分なデー夕数を確保できるようになったと言える。

一方，新規な触媒を探索するための 1 次スクリーニングでは 一度の実験でさらに多くの触媒の活性評価が必要である。384 マイクロプレート型の反応器を用いる試みも報告されており 少なくともこの程度の数の反応ラインが望ましいと言える。ウ エル数を増加することで，スクリーニングの効率の向上が期待 されるが, 同様の反応器を加圧条件下で用いるためには, ガス の分岐用ジョイント, 減圧用デバイスなどが必要となり実現の ためにはコストも問題となる。Fig. 1(a) は，12 個の触媒をパ ラレルに評価する装置に用いられた触媒容器の略図 ${ }^{1)}$ であり, 全ての触媒容器を入れる高圧容器, ガス供給ライン, ガス分析 装置等を除いて, 図に示された一つの触媒用ラインだけで拈よ そ14,000 円程度のコストがかかった。一方, Fig. 1(b) は96 個 の触媒を評価可能な装置6)に用いた触媒容器とそのラインの略

* To whom correspondence should be addressed.

* E-mail: omata@erec.che.tohoku.ac.jp
図で, ダーラム管内の触媒層拉よびその下のガラスビーズ層に は 2 本の SUS チューブをまとめて挿した注射針が貫通してい る。ここに示されたラインのコストは 9,000 円程度である。し たがって，これらの方式をそのままさらに多くのラインを有す る HTS 反応器の作製に用いるのはコスト的に困難であり, 特 にラインの接続用抢よび減圧用のデバイスコストを削減しない 限り 384 マイクロプレート型によるHTS 反応器によるスクリ (a)

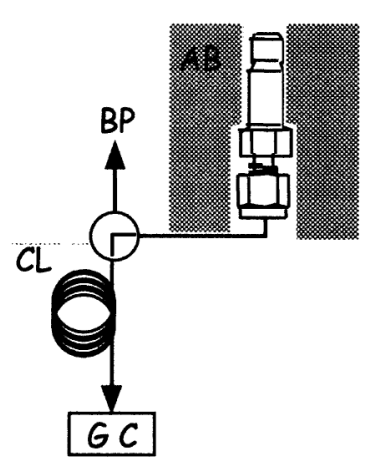

(b)

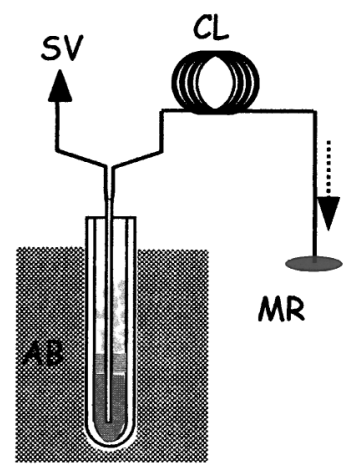

(a) Line for 12 catalyst vessels costing JPY 14,000, (b) Line for 96 catalyst vessels costing JPY 9,000.

$\mathrm{AB}$ : aluminum block, BP: back-pressure regulator, CL: capillary loop, GC: gas chromatograph, MR: microplate reader, SV: stop valve.

Fig. 1 Reaction Lines for Individual Catalyst Vessels 


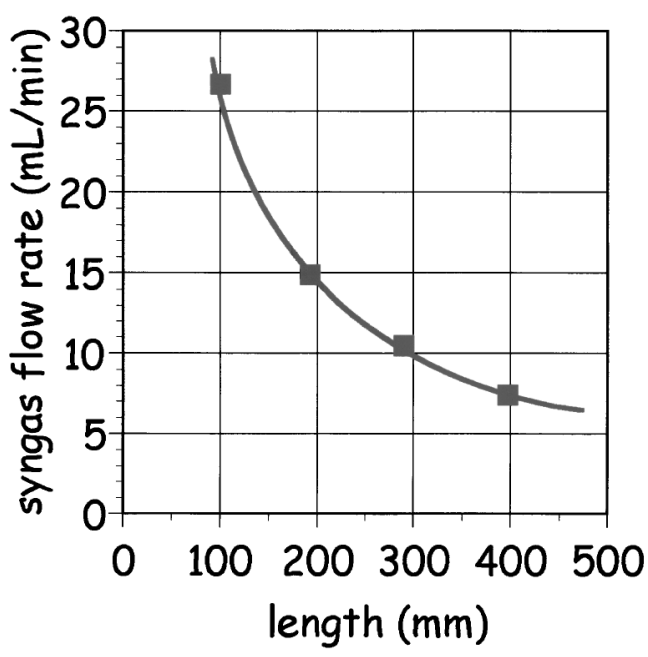

Fig. 2 Effect of Tube Length on Gas Flow Rate at $1 \mathrm{MPa}$, $\mathrm{H}_{2} / \mathrm{CO} / \mathrm{CO}_{2} / \mathrm{Ar}=60 / 30 / 5 / 5$ Molar Ratio, I.D. $=50 \mu \mathrm{m}$

ーニング効率向上は単なる理論的予想で終わってしまう。

384 ウェルマイクロプレートフォーマットで，ほぼ $8 \mathrm{~cm} \times$ $12 \mathrm{~cm}$ のサイ゙に 16 行 24 列の穴が並んで拉り，一つの穴のサ イズが $5 \mathrm{~mm}$ 弱と小さく, また数も多いため 96 ウェルでそう したようにキャピラリーチューブを二本ずつ挿入（Fig. 1(b)) するのは困難である。したがって，12 ライン HTS（Fig. 1(a)） のように反応ガスを触媒層の下から抜き出さざるを得ない。ま た，個々のラインも細い方が望ましいがラインの接続に市販の 高圧継ぎ手を用いることは，技術的・経済的に困難である。こ のような，サイズ，形状，コストの制約の中で種々試行錯誤を 繰り返した後，熱収縮チューブによる配管の接続㧍よび互換式 注射針の利用に至った。本報告ではこれらの安価なデバイスお よびそれらを用いる HTS 反応器を試作したので報告する。

\section{2. 実験}

配管には外径 $0.3 \mathrm{~mm}$ ，内径 $0.1 \mathrm{~mm}$ の SUS 製チューブを用 い，その接続には収縮後の内径が $0 \mathrm{~mm}$ となる特殊な熱収縮于 ユーブを用いた。反応後のガスの減圧には, 外径 $0.375 \mathrm{~mm}$, 内径 $50 \mu \mathrm{m}$ ，長さ $15 \mathrm{~cm}$ のシリカ製チューブを用いた。

メ夕ノール合成反応は内径 $11 \mathrm{~cm}$, 内面高さ $6 \mathrm{~cm}$ の SUS 製 高圧 HTS 反応器中, 流通式で $1 \mathrm{MPa}, 498 \mathrm{~K}, W / F$ は約 $1 \mathrm{~g}$. $\mathrm{h} / \mathrm{mol}$ にて行った。SUS 製の互換式注射針を流用した触媒容器 に市販の銅系酸化物触媒（ズードケミー社製触媒，MDC-3, $\phi 3 \mathrm{~mm}$, 高さ $3 \mathrm{~mm}$, 円筒状) を一粒 (約 $50 \mathrm{mg}$ ) ずつ充填後 反応ガス $\left(\mathrm{H}_{2} / \mathrm{CO} / \mathrm{CO}_{2} / \mathrm{N}_{2}=60 / 30 / 5 / 5\right)$ を流通させ， $523 \mathrm{~K}$ まで 昇温することで活性化を行った。活性は空時収率 (STY, g$\mathrm{MeOH} / \mathrm{kg}$-cat./h) で表した。反応は 3 時間行い, 生成したメ夕 ノールは，96 ディープウェルマイクロプレートの各ウェル中 の水に別々に吸収し, 呈色反応により定量した6)。

\section{3. 結果と考察}

Fig. 2 に内径 $50 \mu \mathrm{m}$ のシリカチューブに合成ガスを流通した 時のチューブ長と流速の関係を示す。チューブの一端は $1 \mathrm{MPa}$,

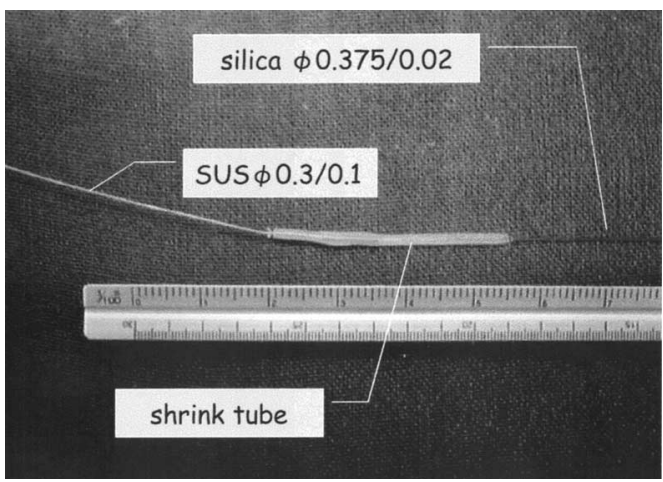

Fig. 3 Two-way Joint and Pressure Regulator

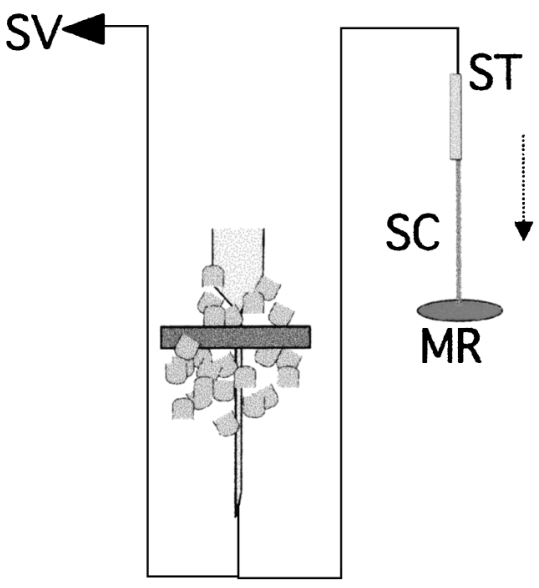

SC: silica capillary tube, ST: shrink tube, SV: stop valve, MR: microplate reader

Fig. 4 Low Cost Reaction Line Costing JPY1,000

他端は常圧として流速を測定した。 $W=50 \mathrm{mg}, W / F=1 \mathrm{~g}$. $\mathrm{h} / \mathrm{mol}$ の条件で各触媒層に合成ガスを流すには $15 \mathrm{~cm}$ のシリカ チューブを使用すればよいことがわかった。このシリカチュー ブと SUS チューブを，長さ $6 \mathrm{~cm}$ 程度の熱収縮チューブを用い て接続し，減圧デバイスを試作した。中央の接合部でSUS 製 チューブ末端がふさがれないように別のテフロンチューブで覆 った。Fig. 3 では分かりやすいように短い熱収縮チューブを使 い, 内部の SUS チューブは赤色のチューブで覆ってある。

シリカチューブの解放端以外の部分の圧力は反応圧と同じ く, $1 \mathrm{MPa}$ となるため, 配管後のガス漏れチェックは必須であ る。キャピラリーチューブを包むように熱収縮がきちんと完了 していればガス漏れは検出されなかった*1)。これらのデバイ スを使い, 触媒容器として注射針を用いて反応ラインを作成し た（Fig. 4)。前処理中は合成ガスは左のラインを流れ, 反応 中はストップバルブを閉めるためにガスは右の圧損の大きなラ

*1) ただし，今回用いた熱収縮チューブは耐圧シールのための ものではない。また，強く引っ張ると抜けることがある。 


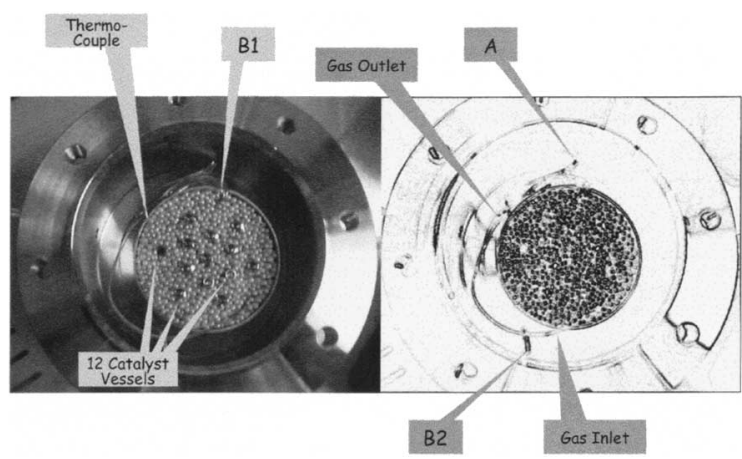

Fig. 5 Photograph of Low Cost Reactor with 12 Lines

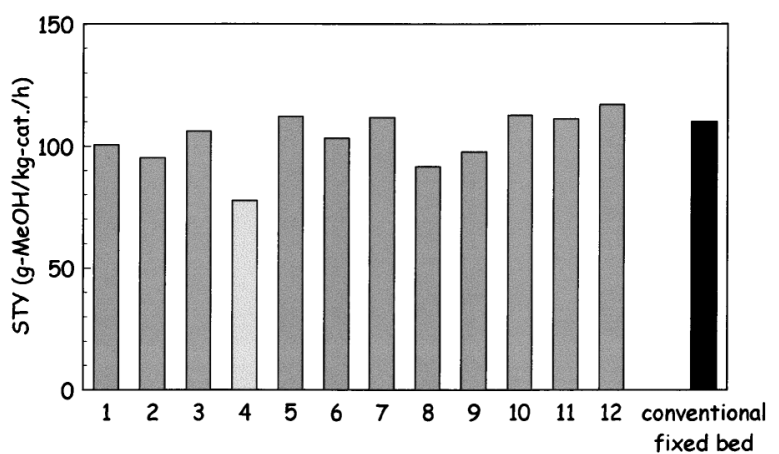

Fig. 6 Activity Evaluation of Identical $\mathrm{Cu}$ Oxide Catalysts
インを流れる。シリカチューブの端は 96 ディープウェルマイ クロプレートに入れたトラップ用の水の中へ挿入されて抢り, シリカチューブにより滅圧された反応ガス中のメタノールはこ の水に吸収される。Fig. 4 の触媒容器を 12 個, 高圧容器（内 径 $110 \mathrm{~mm}$ ) に入れ (Fig. 5), Cu 系酸化物触媒を各触媒容器 に充填して反応に供した。

左右の図は同じ写真をコントラストを変えて示してある。高 圧 HTS 反応器内部中央の容器は底がフラットなアルミニウム 製で, ここに 12 個の触媒容器とその下から出ている SUS チュ ーブ 24 本，㧍よび触媒容器を均温とするための銅粒（2３ $\mathrm{mm}$ 径) が充填されている。 $\mathrm{A}$ の穴からは反応ガスの導入，排 出用 SUS チューブが各 1 本とシース熱電対が入っている。反 応ガスは A を通るチューブから入り各触媒層を抜けるほかに, A を通る他方のチューブからも外部に出ている。このラインに は背圧弁が備えてあり, 各触媒層からのガスの流出量が変動し ても高圧 HTS 反応器の圧力を一定に保てるようにしている。 したがって, 各触媒層から出たガスが減圧されるシリカチュー ブには常に一定の差圧がかかっている。また，転化率は高々 数\%となるように反応条件を設定してあるため, シリカチュ ーブを通るガスの組成もほぼ同じと見なせることから各触媒層 のガス流量はほぼ等しいと言える。

各触媒容器から出た合計 24 本のラインはアルミ容器の B1 のふちからアルミ容器の外周を廻り, B2 の穴から外部に出て いる。B2 の箇所の筋は 24 本の SUS 管を束ねたものである。 そのうち 12 本はストップバルブへ接続され, 残りの 12 本はシ リカチューブを通過して常圧まで減圧され，96 ディープウェ ルマイクロプレートに入れたメタノールトラップ用の水を通過 後ドラフトへ排気されている。本反応では生成物への選択性が 高く, 生成物による反応阻害もないため, W/F と転化率が比例 する低転化率領域で反応を行う限り, 多少触媒ごとにW/Fが 異なっていてもこのようにしてトラップしたメタノールの蓄積 量から STYを正しく評価できる。ただし，上記のように差圧 は固定されてしまうので, $W / F$ を変えるときには反応圧力を変 えるか, 触媒充填量を変えるか, シリカチューブを取り替える か, しかない。図には示さないが, 触媒充填後, 温度分布をフ ラットにするためにさらに全体を $5 \mathrm{~mm}$ 径程度のアルミ粒で覆 い反応に供した。このラインのコストは 1 ライン当たり 1,000 円程度であった。
HTS 反応の一次スクリーニングで数多くの触媒を評価する ためには, 様々な要素を切り捨ててしまい, 最も必要な観点か らのみ評価するのが通常である。たとえば, 薄膜状に形成した 触媒に反応ガスを吹き付けるとともにその周辺のガスを質量分 析へ導入して, 生成物量がある程度以上の濃度かどうかをチェ ックする方法はその最たるものであろう。この手法は固体触媒 の定量的な活性評価とは言えないが，スクリーニングの速度は 尋常ではない。要はスクリーニングの目的次第である。本報告 の反応装置では一応固定床流通式反応器の体裁をとっているも のの, 触媒の粒径（外径 $3 \mathrm{~mm}$ ) が反応容器内径 $(4.5 \mathrm{~mm})$ に 近く, 反応ガスの吹き抜けなどの可能性もあることから，どの 程度定量的な活性評価を行えるかについては慎重に検討する必 要がある。Fig. 6 に 12 個の触媒の活性を示す。

活性は No. 4 を除いて $104 \pm 13$ g-MeOH/kg-cat./h と, 20/36メ ッシュに整粒した触媒を用いた従来の固定床反応器による測定 結果と近いことから, 前報の触媒容器1),6) と同等の性能を示し ていると言える。また, 触媒粒子サイズが大幅に異なっている にもかかわらず反応温度, 圧力が等しい条件下でほぼ同じ活性 が得られているため Thiele 数と触媒有効拡散係数の関係図に 当てはめると触媒有効拡散係数はかなり良いと言える。一方, 20/36メッシュ触媒粒子の見かけ比重はほぼ1であったので, この場合の空げき率は $55 \%$ であるが, 内径 $4.5 \mathrm{~mm}$ の注射針 に外径 $3 \mathrm{~mm}$ の触媒粒子を入れるとやはり空げき率は $55 \%$ と なる。このように空げき率が同程度であることも留意点として 挙げられよう。

以上のことから, 本装置を $225^{\circ} \mathrm{C}, 1 \mathrm{MPa}$ でのメ夕ノール合 成反応に用いる場合には 2 次スクリーニング用の定量的な評価 も可能であると言える。ただし, No.4ラインについては, 減 圧用キャピラリーの接合部が詰まったために流速が低下して $W / F$ が上昇したことが $S T Y$ 低下の原因であった。反応器作製 後の流速の念入りなチェックが必要である。

今後, 同様の安価なアセンブリを用いて, さらに多くのライ ンを有する HTS 反応器の作製を予定している。

\section{謝 辞}

本研究は, 日本学術振興会未来開拓学術研究推進事業におけ る研究プロジェクト「低環境負荷型高品位輸送用燃料の合成」 （JSPS-RFTF98P01001）ならびに, 文部科学省 21 世紀 COE プ 
ログラム「大分子複雑系未踏化学」により行われており，ここ に感謝します。

\section{References}

1) Omata, K., Ishiguro, G., Yamada, M., Sekiyu Gakkaishi (J. Jpn. Pertol. Inst.), 43, (4), 317 (2000).

2) Omata, K., Umegaki, T., Ishiguro, G., Yamada, M., Sekiyu Gakkaishi (J. Jpn. Petrol. Inst.), 44, (5), 327 (2001).

3) Omata, K., Umegaki, T., Watanabe, Y., Yamada, M., J. Jpn. Petrol. Inst., 45, (3), 192 (2002).

4) Umegaki, T., Omata, K., Ishiguro, G., Watanabe, Y.,
Yamada, M., J. Jpn. Petrol. Inst., 46, (3), 181 (2003).

5) Omata, K., Umegaki, T., Watanabe, Y., Nukui, N., Yamada, M., J. Jpn. Petrol. Inst., 46, (3), 189 (2003).

6) Omata, K., Watanabe, Y., Umegaki, T., Hashimoto, M., Yamada, M., J. Jpn. Petrol. Inst., 46, (5), 328 (2003).

7) Omata, K., Hashimoto, M., Watanabe, Y., Umegaki, T., Yamada, M., J. Jpn. Petrol. Inst., 46, (6), 383 (2003).

8) Omata, K., Watanabe, Y., Hashimoto, M., Umegaki, T., Yamada, M., J. Jpn. Petrol. Inst., 46, (6), 387 (2003).

9) Klein, J., Zech, T., Newsam, J. M., Schunk, S. A., Appl. Catal. A: General, 254, 12 (2003).

要旨

メタノール合成触媒の評価に用いるハイスループットスクリーニング反応器用廉価配管デバイスの考案

小俣光司，橋本正彦，渡辺裕輔，スタルト，梅垣哲士，山田宗慶

東北大学大学院工学研究科, 980-8579 仙台市青葉区荒卷字青葉 07

著者らの開発した 96 ウェルマイクロプレートを用いる HTS (high-throughput screening) 反応器は, メ夕ノール合成用 7 成 分銅系触媒の組成最適化などの用途には十分な数のリアクター ラインを有しているが, 新規な触媒を探索するための 1 次スク
リーニングにはさらに多くのリアクターラインが必要な場合が ある。そのような多数のラインの配管に必要となる安価なデバ イスならびにそれを用いる安価なメタノール合成触媒開発用 HTS 反応器を試作したので報告する。 